\title{
Urban Gardening in Florence and Prato: How a Science Shop Project Proposed by Citizens Has Grown into a Multi-Disciplinary Research Subject
}

\author{
Franco Bagnoli ${ }^{1,5}$, Ada Baldi ${ }^{4}$, Ugo Bardi ${ }^{2}$, Marina Clauser ${ }^{3}$, Anna Lenzi $^{4}$, Simone Orlandini ${ }^{4} \&$ Giovanna Pacini ${ }^{1,5}$ \\ ${ }^{1}$ Dept. Physics and Astronomy and CSDC, University of Florence, Sesto Fiorentino (FI), Italy \\ ${ }^{2}$ Dept. Chemistry, University of Florence, Florence, Italy \\ ${ }^{3}$ Botanic Garden, Natural History Museum, University of Florence, Florence, Italy \\ ${ }^{4}$ Dept. Agrifood Production and Environmental Sciences, University of Florence, Florence, Italy \\ ${ }^{5}$ Associazione Caffé-Scienza Firenze-Prato, Italy \\ Correspondence: Franco Bagnoli, Dept. Physics and Astronomy and CSDC, University of Florence, Sesto Fiorentino (FI), Italy. \\ E-mail: franco.bagnoli@unifi.it
}

Received: July 4, $2018 \quad$ Accepted: September 19, $2018 \quad$ Online Published: November 29, 2018

doi:10.5539/jsd.v11n6p111 URL: https://doi.org/10.5539/jsd.v11n6p111

\begin{abstract}
Urban gardening mainly means growing edible vegetables in a town. This practice has been traditionally used for economic reasons (subsistence agriculture), but now it has also acquired educational, nutraceutical, therapeutic and social relevance. The educational aspect of urban gardening has been the subject of a proposal for the newly born Science Shop in Florence (Italy). In the spirit of action-research, in our project we first decided to involve all (or many) potentially interested people. This has brought into light the galaxy of different aspects related to urban gardening and allowed the establishing of promising research lines. We discovered that this is a multi-disciplinary subject that touches themes dealing with agriculture, botany, psychology, chemistry, city planning and politics. We examine here the various aspects of urban gardening in the towns of Florence and Prato, two very different urban environments despite their proximity.
\end{abstract}

Keywords: urban gardening, social gardening, science shops

\section{Prelude: Science Shops}

A Science Shop is a way of opening the University to problems and questions coming from the society. In this methodology, citizens and their associations are invited to express their problems, that are then focussed in some public encounters. This originates one or more research projects that are supervised by some researchers, but carried on by students, in interaction with the interested citizens and associations.

In Europe, there is a wide variety of examples of this approach, with many variations. One of the oldest examples is the Athena Science Shop of the Vrije University of Amsterdam. They mainly work on four research themes: Emerging Technologies and Society, Health, Sustainability and Society, Education for Science and Society.

One of the most recent Science Shops is the Boutique Des Sciences of the University of Lyon, that was born thanks to an European Project (PERARES, 2010). As an example of their last projects, related to the theme of this paper, we like to mention "Urban gardening: comparative study of pollution influence on the quality of the vegetable production in town and in the country".

Even though there are many different methodologies (Living Knowledge 2018), the traditional Science Shop approach consists in receiving the proposal, performing the investigation and reporting the results.

The EU project InSPIRES has the goal of exploring the possibility of a "Science Shop 2.0" improvement. In this approach, the evolution of the received proposal is much more interactive than in the classic scheme: the original subject is elaborated by a multi-disciplinary team, open to citizens, though public encounters like Science Cafés. The aim is to profit from the occasion to promote joint collaboration among different researchers (and their students), and to engage lay people as both proposers, evaluators and citizen scientists. 
The urban gardening issue in Florence was proposed first by an association, Orti Dipinti, which uses them as a didactic tool (Orti Dipinti, 2018), and by a group of students who urged the Green Office of the University of Florence (Ateneo Sostenibile, 2018) to promote the development of gardens administered by themselves in the vicinity of some university canteens.

As reported in detail in Section 6, this topic was presented and discussed for the first time in a science café, on November 17 $7^{\text {th }}, 2017$ (Orti Urbani Science Cafè, 2017) thanks to the Florence Science Café Association (Caffè-Scienza, 2018) and a project started about producing a booklet resuming all the different aspects of urban gardening, including the emotional and technical ones. In this paper we present the first "results" emerging from this Science Shop project, that uncovered the rich galaxy of topics related to urban gardening, in particular in the towns of Florence and Prato in Italy, where research actions are taking place.

\section{Introduction: Urban Gardening}

The term "urban garden" combines two words that, in the common thought, have opposite values: the idea of the garden is linked to the growing of vegetables in the countryside, whereas with urban we normally refer to cities and in general to industrialized areas.

On the contrary, the concept of "urban agriculture" or "urban gardening" is probably as old as the existence of cities themselves. In fact, looking at the historical maps of urban areas (from the Romans to the present day) it is possible to see plots of cultivated land inside the city walls.

While, however, in the past these urban gardens had only the purpose of producing food, today the society is discovering also their social and educational aspects, as well as their utility for the requalification of degraded areas, as shown by a study of some Canadian communities that deals with degraded suburbs (Duchemion, 2009) and the example of Ron Finley, the "guerrilla gardener" (Finley Ron, 2018), a designer who bought an abandoned land in Los Angeles and turned it into an urban garden.

Even today, however, food production is the main objective of these activities. Indeed, the $15 \%$ of world food is grown in cities (USDA, 2013) and, according to FAO (United Nations Food and Agriculture Organization) urban farms supply food to about a quarter of the world's urban population, increasing the level of food security (Kourous, 2005).

There are, anyway, several ways to develop the concept of agriculture in urban gardens (Foodtank 2015, Epstein 2016, Shemkus 2014), which can be practiced not only with the aim to produce food but, for instance, also as a way to provide accessory services in big cities. An example of the first goal is "LocalSprout" (LocalSprout 2018), an urban hydroponic farm, while the "Brooklyn Grange Rooftop Farm" in New York is a perfect example of an aesthetic use of gardening: two roofs of about 11 hectares covered by cultivated patches (Brooklin Grange 2018).

In Italy we have a long history of subsistence gardening. If in rural areas people has always been growing their own vegetables, vegetable crops have been present in urban areas since the first half of the $19^{\text {th }}$ century (Tei and Gianquinto, 2010). At that time, as well as in other parts of the world during periods of industrialization, agricultural activity in and around the cities was carried out by people who had moved from rural areas to work in the factories and who lived in poverty. In the 1940s, urban gardens increased in number and became "war-gardens" (Ferrari, 1919), aimed to face food shortage in the cities due to the breaking down of the supply lines from the country caused by the war (Barthel et al., 2015). After the Second World War, with the increasing value of urban land, agriculture moved from urban to peri-urban areas, especially in the northern cities due to the workers immigrating from the South (Tei and Gianquinto, 2010). It is exactly in the peri-urban areas that agriculture for self-supply is largely practiced still today in Italy. There is also an interest of young people in “caming back" to agriculture (Mucci, 2014, Lovett, 2018), although statistical data do not confirm this perceived trend (Comegna, 2018).

Nowadays, urban gardens are assigned by municipalities after public calls to individual citizens (often retired workers), but there are many private gardens (front and back courtyards or balconies) or community gardens where people collaborate in a common effort.

The techniques used for cultivation are different. The most common method is the traditional one (Fig. 1), but there are also gardens with hydroponic cultivation and gardens with high productivity methods (often used in community gardens, Figs. 2 and 3). 


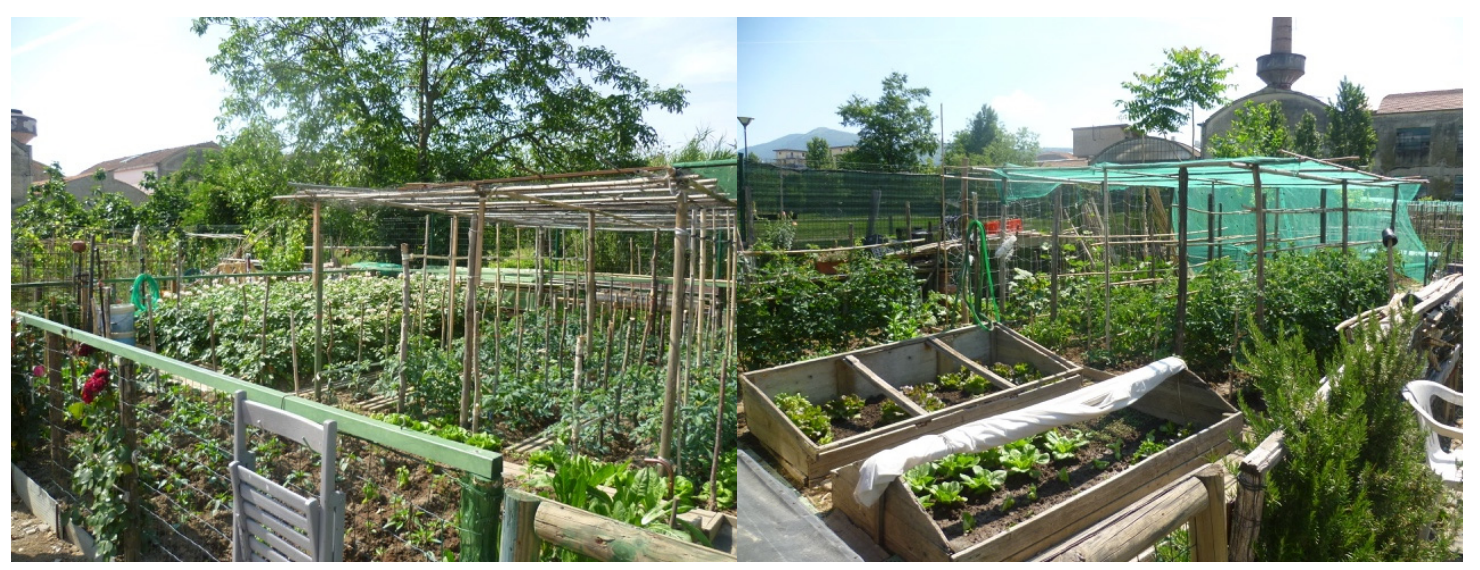

Figure 1. Some views of a social/community garden in Prato

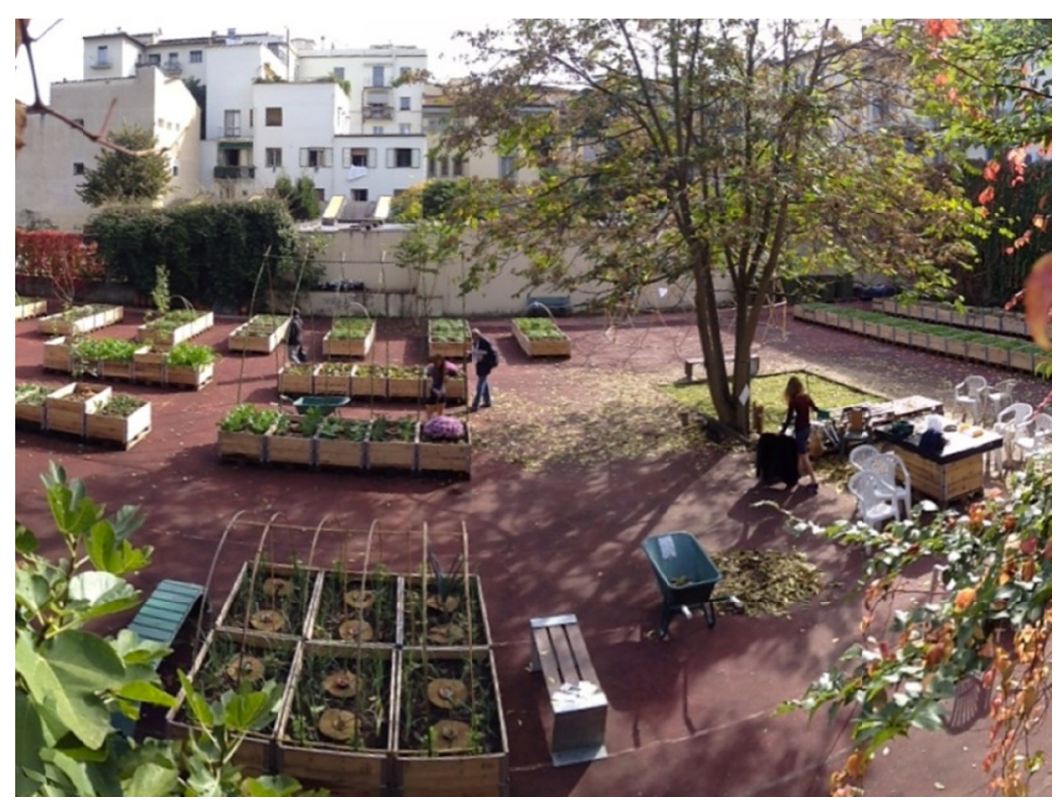

Figure 2. Urban gardening in Orti Dipinti (Orti Dipinti 2018) 


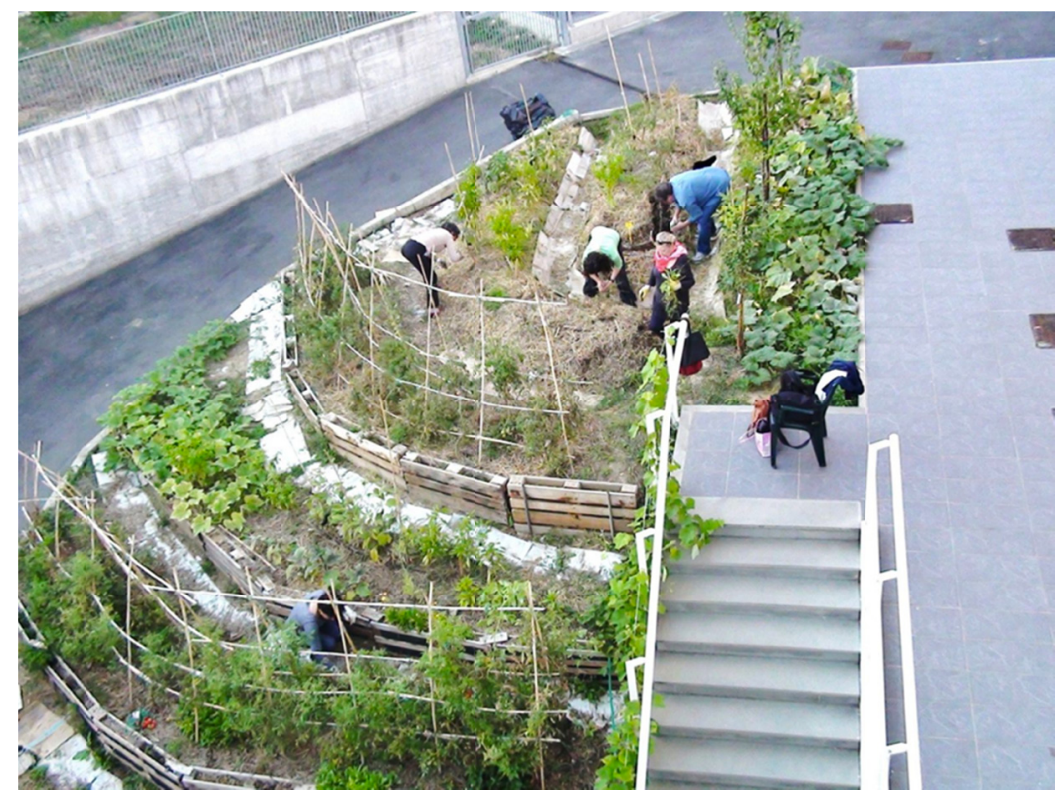

Figure 3. Biblio-orto (biblio-garden) near BiblioteCaNova, Isolotto area of Florence (BiblioteCaNova 2018)

\section{The Towns of Florence and Prato}

Florence is the capital of Tuscany Region, in central Italy, and about one million inhabitants live in its metropolitan area. While the city is known as one of the most important towns of art and architecture thanks to its numerous monuments and museums, it also holds manifacturing enterprises and other productive activities.

Prato is the second largest city of Tuscany, the third of central Italy by number of inhabitants. The economy of the city and of the neighboring municipalities is mainly based on the textile industry, born in the Middle Ages, but developed in the nineteenth century. Prato is still today one of the most important industrial districts in Europe.

The total density of green areas (protected natural areas and urban green areas) in 2016 for Florence and Prato is $8 \%\left(8.184 \mathrm{~km}^{2}\right)$ and $8.5 \%\left(8.279 \mathrm{~km}^{2}\right)$, respectively (Istat, 2017).

Table 1. Percentage of green areas in Florence and Prato (2016)

\begin{tabular}{llll}
\hline Municipality & Surface $\left(\mathrm{km}^{2}\right)$ & Percentage of green areas & Inhabitants \\
\hline Florence & 102.3 & 8.0 & 382,258 \\
\hline Prato & 97.4 & 8.5 & 192,469 \\
\hline
\end{tabular}

Table 2. Composition of green areas in Florence and Prato (2016)

\begin{tabular}{llllllllllll}
\hline Municipality & His. & Par. & Pl. & Furn. & For. & Sch. & Bot. & Gard. & Sp. & Cem. & Oth. \\
\hline Florence & 34.6 & 7.9 & 5.6 & 6.5 & 0.6 & 8.1 & 0.3 & $\mathbf{0 . 9}$ & 20.3 & 4.2 & 11.0 \\
\hline Prato & 41.0 & 1.3 & 36.0 & 10.8 & 0.4 & 4.1 & - & $\mathbf{0 . 1}$ & 5.9 & 0.4 & - \\
\hline
\end{tabular}

Legend: His.: Historical gardens; Par.: Parks and urban forests; Pl.: play grounds; Furn.: Street furnitures; Sch.: School gardens; Bot.: Botanical gardens; Gard.: urban gardens in bold; Sp.: sport areas; Cem: Cemeterial gardens; Oth. Other, mainly Zoological gardens.

\section{Urban Gardening in Florence}

During the past few years, also the town of Florence has witnessed the widespread desire for a more "natural" way of living, shared by many young people.

As in all ancient towns, also in the city of Florence urban gardens were normally present in medieval and 
previous times, especially in convents where monks or nuns cultivated aromatic herbs or vegetables to support their community and to be able to help the most needy people. At the beginning of the Renaissance, the boundary walls of Florence were enlarged forecasting an impetuous growth, which was however stopped by the pestilence of 1348. As a result, many areas inside the walls remained empty and were then used as gardens or urban parks. The urban structure of the town remained similar in subsequent years, as it can be seen by comparing the map of the year 1500 with that of 1800 . When Florence became the temporary capital of Italy, in 1870, the walls were destroyed, following the example of Vienna, and a lot of surrounding urban areas were occupied by new buildings. Finally, during the Second World War, Florence suffered of some damages and new buildings replaceed some ancient ones, without drastic changes in the urban plan. In all these times, it was customary for many buildings in the periphery to have a small garden, accessible to citizens living on the ground floor. However, most of citizens since 1950's onward have not had any contact with cultivations and plants, except for public parks and gardens.

In recent years, also thanks to the project "One hundred thousand gardens in Tuscany" promoted by the Tuscan Regional government, the idea of urban co-gardening (gardens assigned by municipalities) is becoming familiar to almost all citizens.

Another interesting initiative in our city was carried out by the "EcoEquo" branch of the Municipality of Florence, which created the "Orto Volante" project (Carpini, 2014). The idea was to monitor urban gardens to study possible improvements, promoting collaboration with associations, institutions and citizens, and organizing guided visits of citizens to no-profit associations and cooperatives working in this area.

\section{Urban Gardening in Prato}

In Prato the tradition was that every building where manufacturing was carried on had a medium-size garden associated with it, to be cultivated by owners and some of the workers. In recent times, abandoned municipal areas have been converted to urban gardens, assigned to citizen by means of public competitions (co-gardening). A study on the related agronomic, environmental, and social aspects, targeted to senior citizens, is being carried out by the Department of Agrifood Production and Environmental Sciences of the University of Florence (DISPAA) for a master degree thesis work (Fig. 1). A questionnaire focusing on the above listed aspects has been already submitted to a first sample of 20 gardeners. The results of this preliminary survey show that, although the gardening activity has an important productive function $(75 \%$ of the interviewed people declared that the produce of the garden covers more than $50 \%$ of the family vegetable consumption), the social aspects (meeting other people and sharing experiences) are crucial: $85 \%$ of participants emphasized the importance of social motivations for joining this initiative.

\section{The Science Shop Project}

The theme of urban gardening is the core of the first project of the Florence Science Shop (2018). It was planned according to the new methodology, trying to enhance the participative and collaborative approach during all the process, from the initial idea to the dissemination of results. The first step was to organize a science café to illustrate the project and the spirit of the Science Shop and to collect questions on the specific topic (Orti Urbani Science Café, 2017).

Three stakeholders with different background played the role of "experts": Ugo Bardi, a physical chemist at the University of Florence and the University delegate for sustainability, Marina Clauser, from the Botanic Garden of Florence, and Giacomo Salizzoni, the president of the no profit association Orti Dipinti (2018). Franco Bagnoli, who moderated the event, introduced the subject and the idea of the Science Shop to the public.

Both citizens and experts proposed research issues and expressed their needs, like for example that of creating a network for the exchange of information, the necessity to have a dialogue with the institutions, the requirement of financial support to urban gardens for social/recreational purposes, and the desire to have answers to questions about the new methods and techniques in horticulture.

After the event, other researchers from DISPAA joined the project. From the point of view of stakeholders, the Municipality of Prato expressed its interest in monitoring the assigned public gardens, and a thesis project on the subject of urban gardens started with a provisional title "Impact of urban horticulture on water resources: the case of the social gardens of the Municipality of Prato".

\section{The Research Group in the University of Florence}

In this urban context, the University of Florence plays an increasingly important role thanks to various initiatives. The "Giardino dei Semplici" Botanical Garden of the University of Florence, (Fig. 4) prepared demonstration gardens suitable also for small spaces and inspired by the "Ortobioattivo" concept (Ortobioattivo, 2018): 
interested people can concretely participate in the cultivation of vegetables, exchange experiences, delve into specific issues (use of self-produced fertilizers, lombricompost, biodynamics, use of biostimulants and corroborants, consociations, effective microorganisms, mycorrhizae, nutraceutical foods, urban beekeeping, food waste, urban vegetable gardens to capture $\mathrm{CO}_{2}$, etc.).

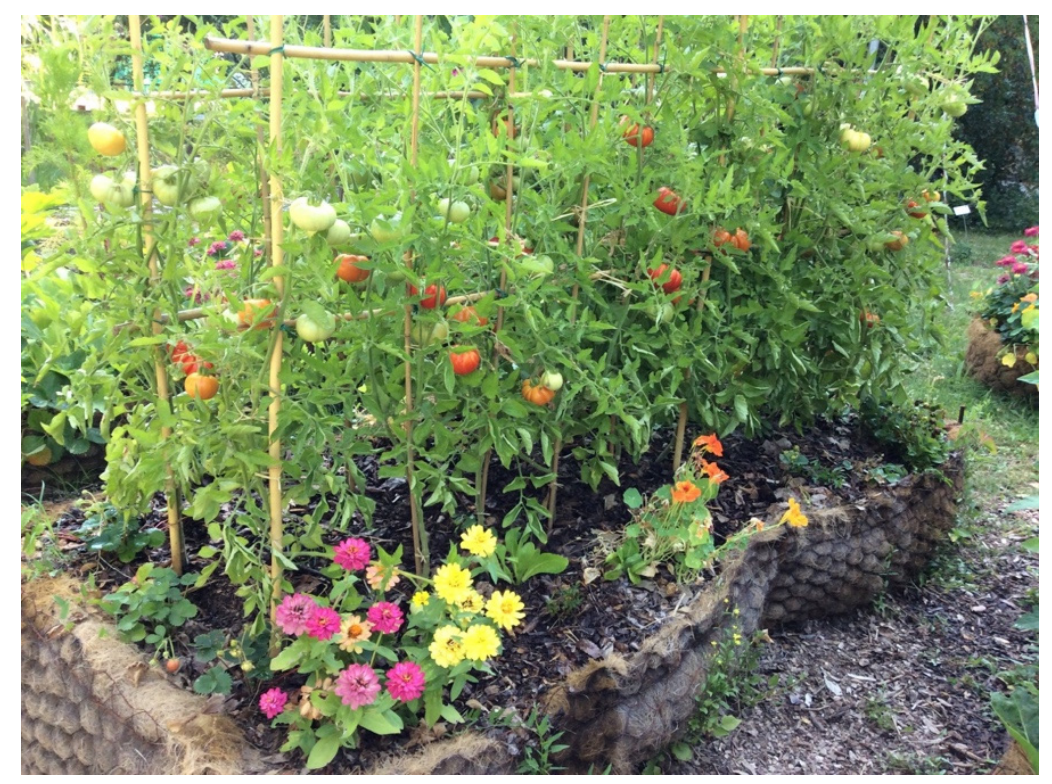

Figure 4. Botanical Garden of Florence

Within the project Ur.C.A. - Urban (Con)Temporary Agriculture (Migliorini, 2017), a modular, movable, hydroponic greenhouse destined to agricultural activity in paved urban areas, was developed by the Department of Architecture (DIDA) in collaboration with DISPAA. Now the greenhouse is assembled at the "Istituto Agrario Firenze", where it is used for didactic activity addressed to high school students. A small-scale hydroponic system suitable for the domestic cultivation of vegetables was also developed within the project (Lenzi et al., 2018).

The Botanical Garden of the University of Florence has also been an experimental site for the biological control of weeds and pathologies for two years: the results are very encouraging, and the experience is actively continuing. At the same time, research is being carried out in collaboration with the University of Florence's Biology Directorate, Cerfit (Regional Reference Center in Phytotherapy) and Ortobioattivo to evaluate the nutraceutical value of plants grown using "bioactive" practices (Ortobioattivo, 2018). Furthermore, the Botanical Garden has been promoting, for more than 10 years and in collaboration with the University Training Office, training courses for staff concerning biological struggling, water saving, best practices, energy saving, etc.

Urban gardening is a topic that the University of Florence deals with also at a didactic level, debating the issue within courses of the offered educational path, like those of the School of Agriculture, and developing it within degree theses.

After a suggestion coming from university students (a kind of pre-Science Shop initiative), the Green Office of the University=, in collaboration with Andrea Battiata (Ortobioattivo, 2018) established some co-gardens in the educational complex of Viale Morgagni (student house), where students themselves supply the university canteen with products from their garden (University co-gardening, 2017), (Fig. 5). 


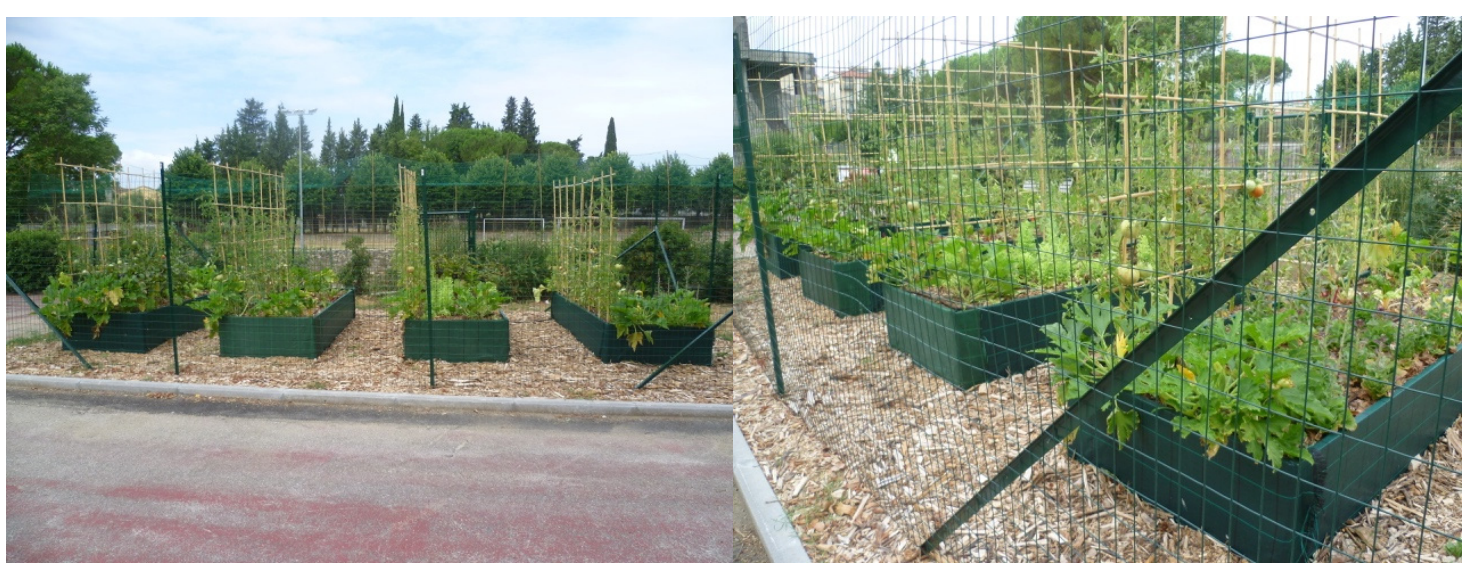

Figure 5. Bio-active University gardens in Viale Morgagni (Florence)

\section{Conclusions and Perspectives}

The theme of urban agriculture is of great interest in Florence and Prato: around this topic private individuals and public institutions are mobilized in a concrete and creative way; there are important experiences of shared gardens and high value of solidarity and inclusion; reflection on the use of land and on common goods is deeply felt and participation in meetings, blogs, events on urban gardens is active and increasing. There is a broad desire to share and exchange experiences, to learn and put into practice sustainable agronomic techniques.

The ongoing Science Shop project about urban gardening is collecting many data about the citizens involved in this practices, technical methodologies used and also emotions and motivations. These data will be presented in future publications and made accessible on the web site of the Florence Science Shop (2018).

\section{Acknowledgements}

The Florence Science Shop "Lo Sportello della Scienza a Firenze" was born thanks to the EU project InSPIRES, "Ingenious Science shops to promote Participatory Innovation, Research and Equity in Science" (InSPIRES 2018)

The university co-garden experience is supported by the Green Office of the University of Florence (Ateneo Sostenibile 2018).

We thank Balázs Balint of ESSRG (ESSRG 2018) and the InSPIRES staff for carefully reading and amending this document.

\section{References}

Ateneo Sostenibile. (2018). Green office of the University of Florence (UNIFI). Retrieved from https://www.ateneosostenibile.unifi.it/

Bagnoli, F., Bardi, U., Clauser, M., \& Pacini, G. (2018). Urban Gardening In Florence: A Social Sustainability Experience. $\quad$ Leading Cities. Retrieved from https://leadingcities.org/2018/03/22/urban-gardening-in-florence-a-social-sustainability-experience/

Barthel, S., \& Isendahl, C. (2013). Urban gardens, agriculture, and water management: Sources of resilience for long-term food security in cities. Ecological Economics, 86, 224-234. https://doi.org/10.1016/j.ecolecon.2012.06.018

BiblioteCaNova. (2018). Isolotto library. public Retrieved from http://www.biblioteche.comune.fi.it/bibliotecanova_isolotto/

Brooklyn Grange. (2018). Rooftop farms. Retrieved from https://www.brooklyngrangefarm.com/

Caffè-Scienza. (2018). Cultural Association. Retrieved from www.caffescienza.it

Carpini, G. (2014). L'orto urbano? In terrazza, in comune o volante, 04/12/2014 Il Reporter. Retrieved from http:/www.ilreporter.it/articolo/118396-lorto-urbano-in-terrazza-in-comune-o-volante

Comegna, E. (2018). Il ritorno dei giovani in agricoltura che non c'è, Agrarian Sciences. Retrieved from https://agrariansciences.blogspot.com/2018/01/il-ritorno-dei-giovani-in-agricoltura.html 
Duchemin, E., Wegmuller. E., \& Legault, A.-M. (2008). Urban agriculture: multi-dimensional tools for social development in poor neighbourhoods, Field Actions Science Reports, Vol. 1. Retrieved from http://journals.openedition.org/factsreports/113

EcoEquo. (2018). Initiative of the Municipality of Florence. Retrieved from http://ambientesostenibilita.comune.fi.it/SportelloEcoEquo/index.html

Epstein, S. (2016). Urban Gardening Around the World, Brookling Botanic Garden 11/15/2016. Retrieved from https://www.bbg.org/news/urban_gardening_around_the_world

ESSRG. (2018). Environmental Social Science Research Group. Budapest. Retrieved from https://www.essrg.hu/en/

Ferrari, N. (1917). L'orto di guerra: come si coltivano e si cucinano gli ortaggi. Comitato bergamasco delle scuole di economia domestica, Tipografia della Società editrice commerciale, pp. 120. Retrieved from http://www.14-18.it/opuscolo/BSMC_CUB0269979/001

Finley, R. (2018). The Gangsta Gardner. Retrieved from http://ronfinley.com/

Florence Science Shop. (2018). La Bottega della Scienza di Firenze. Retrieved from http://science-shop.complexworld.net/

Foodtank. (2015). 28 Inspiring Urban Agriculture Projects. Retrieved from https://foodtank.com/news/2015/07/urban-farms-and-gardens-are-feeding-cities-around-the-world/

Giardino dei Semplici. (2018). Botanic garden. Retrieved from https://www.msn.unifi.it

InSPIRES. (2018). Ingenious Science shops to promote Participatory Innovation, Research and Equity in Science. EU project. Retrieved from http://www.inspiresproject.eu/

Istat. (2017). Ambiente Urbano. Retrieved from http://www4.istat.it/it/archivio/207482

Kourous, G. (2005). Farming in urban areas can boost food security. Food and Agriculture Organization of the United Nations, FAO Newsroom 6/3/2005. Retrieved from http://www.fao.org/Newsroom/en/news/2005/102877/index.html

Le, R. (2018). Social cooperative. Retrieved from http://www.cooperativasocialelerose.it/Home_html

Lenzi, A., Secci, S., Boganini, L., Casazza, C., \& Sala, M. (2018). A small-scale floating system for the domestic production of vegetables. In Orsini F. et al. (Eds.), Greener Cities for more efficient ecosystem services in a climate changing world (pp. 12-15). Proceedings of GreenCities2017 conference, Bologna. https://doi.org/10.17660/ActaHortic.2018.1215.26

Living Knowledge. (2018). The International Science Shop Network. Retrieved from https://www.livingknowledge.org/

Local Sprout. (2018). Social association. Retrieved from http://www.localsprout.com/

Lovett, P., Essoo G., \& Viala F. (2018). Why Italian graduates are choosing life on the farm, Focus. France 24. Retrieved from https://www.france24.com/en/20180215-focus-italy-youth-graduates-countryside-farming-agriculture-busin ess-employment

Migliorini, F. (2017). Firenze, dall'Università la serra tecnologica che non ha bisogno di terriccio, La Repubblica, 20/06/2017. Retrieved from http://firenze.repubblica.it/cronaca/2017/08/02/foto/firenze_la_serra_tecnologica_targata_unifi-172197624/ $1 / \# 1$

Mucci, A. (2014). Young Italians finding prospects on the farm. News Grid. Retrieved from https://www.aljazeera.com/indepth/features/2014/11/young-italians-finding-prospects-farm-2014112312154 7666768.html

Orti Dipinti. (2018). Nonprofit association. Retrieved from http://www.ortidipinti.it/it/

Orti Urbani Science Café. (2017). An event of the Caffè-Scienza association in Florence. Retrieved from http://www.caffescienza.it/programma-2017-2018/orti-urbani

Ortobioattivo. (2018). Semele cooperative. Retrieved from http://www.ortobioattivo.com

PERARES. (2010). Public Engagement with Research And Research Engagement with Society. EU project. Retrieved from https://www.livingknowledge.org/projects/perares/ 
Shemkus, S. (2014). Next-gen urban farms: 10 innovative projects from around the world. The Guardian $7 / 2 / 2014$. Retrieved from https://www.theguardian.com/sustainable-business/2014/jul/02/next-gen-urban-farms-10-innovative-project s-from-around-the-world

Tei, F., \& Gianquinto, G. (2010). Origini, diffusione e ruolo multifunzionale dell'orticoltura urbana amatoriale. Review n. 11 - Italus Hortus, 17(1), 59-73.

University co-gardening. (2017). Social initiative of the University of Florence. Retrieved from https://www.unifi.it/art-2745-ateneo-sostenibile-presentati-gli-orti-in-viale-morgagni.html

USDA. (2013). United States Department of Agriculture, National Resource Conservation Service. Small Farmers \& Urban Agriculturalists Small Farmers \& Urban Agriculturalists. Retrieved from https://www.nrcs.usda.gov/Internet/FSE_DOCUMENTS/stelprdb1083296.pdf

\section{Copyrights}

Copyright for this article is retained by the author(s), with first publication rights granted to the journal.

This is an open-access article distributed under the terms and conditions of the Creative Commons Attribution license (http://creativecommons.org/licenses/by/4.0/). 